\title{
Crop Response to Soil Acidity Factors in Ultisols and Oxisols in Puerto Rico-Soybeans ${ }^{1,2}$
}

\author{
Fernando Abruña, José Rodríguez, José Badillo-Feliciano, Servando \\ Silva, and José Vicente-Chandler ${ }^{3}$
}

\begin{abstract}
The effect of various soil acidity factors on yield and foliar composition of soybean (Glycine max (L) Merrill) were determined in three Ultisols and one Oxisol. Soybeans responded strongly in yield and foliar composition to variations in soil acidity of the Ultisols and to a lesser extent to variation in acidity of the Oxisol. The best correlations were obtained with the Corozal soil (Ultisol) where the yields were increased from $62 \mathrm{~kg} / \mathrm{ha}$, when the Al saturation was over $60 \%$, to about $2,000 \mathrm{~kg} / \mathrm{ha}$, when the Al saturation was less than $10 \%$ (pH 5.6).

The least response was obtained with the Coto soil (Oxisol, irrigated). The highest yield of $3,555 \mathrm{~kg} / \mathrm{ha}$ was obtained when the Al saturation was less than $10 \%$. About $71 \%$ of the maximum yield was obtained at over $30 \%$ Al saturation ( $\mathrm{pH} 4.3)$.

Variation in the acidity factors significantly affected the $\mathrm{N}$ and Ca content of the soybean leaves on the Ultisols, whereas the other nutrients were unaffected. In the Oxisol, only the $\mathrm{Mn}$ content was affected. Nodulation in the Ultisols was severely reduced as the percent Al saturation increased.
\end{abstract}

\section{INTRODUCTION}

Low crop yields in the humid tropics are often associated with soil acidity factors such as toxic $\mathrm{Al}$ or $\mathrm{Mn}$ concentrations, low $\mathrm{pH}$, and low base saturation. Heavy applications of residually acid fertilizers, if not complemented by adequate liming, can aggravate soil acidity problems. For example, Abruña et al. (1) found that the continuous use of ammonium sulfate sharply increased soil acidity in a typical Ultisol of Puerto Rico.

Crops frequently respond strongly to liming on typical Oxisols and Ultisols in Puerto Rico. Abruña and Vicente-Chandler (2) found that sugarcane growing on an acid Ultisol (Humatas) responded strongly to liming. Abruña et al. (3) found that tobacco responded strongly to liming on an Ultisol and that yields were inversely correlated with percent Al saturation of the soil. They also found that Mn toxicity seemed to be the most important acidity factor affecting tobacco yields

${ }^{1}$ Manuscript submitted to Editorial Board October 15, 1976.

2 This paper covers work carried out cooperatively between the Agricultural Research Service, USDA, and the Agricultural Experiment Station, College of Agricultural Sciences, Mayagüez Campus, University of Puerto Rico, Rio Piedras, P.R.

${ }^{3}$ Soil Scientist, Agricultural Research Service, USDA, Assistant and Associate Agronomists, Agricultural Experiment Station, University of Puerto Rico, Mayagüez Campus, Agricultural Technician, and Soil Scientist-Location Leader, Agricultural Research Service, USDA, respectively, Río Piedras, P.R. 
on an Oxisol. Abruña et al. $(4,5)$ found that corn and green beans responded strongly to liming on acid Ultisols, and that the response was inversely correlated with exchangeable $\mathrm{Al}$ in the soil, and that these crops responded less to liming on an acid Oxisol.

Soybean (Glycine $\max (\mathrm{L})$ Merrill) production is rapidly expanding in the humid tropics and is becoming an important low-cost source of protein, the main deficiency in the diet of millions of people in these areas. In Puerto Rico, Silva et al. (12) found that soybeans of the Hardee variety could produce about $4,000 \mathrm{~kg} / \mathrm{ha}$ in May or June plantings and about $2,400 \mathrm{~kg} / \mathrm{ha}$ in plantings between February and September.

Considerable research has been conducted recently in the tropics on the effects of liming on soybean production. Milkenson et al. (10) in Brazil reported a response of soybeans to liming on a Latosol with an initial $\mathrm{pH}$ below 5. Mascarenhas et al. (9) in Brazil found that soybean yields were increased about $30 \%$ from liming a red Latosol with an initial $\mathrm{pH}$ of 5.5 and only trace amounts of exchangeable Al. Foster (8) reported similar results in Uganda. Soares et al. (13) found that soybean yields on two dark red Latosols in Brazil were sharply increased by applying $5 \mathrm{t} / \mathrm{ha}$ of lime, which reduced $\mathrm{Al}$ saturation of the soil to $10 \%$. On the other hand Armiger et al. (6) reported that soybeans are relatively tolerant to exchangeable soil Al. Thus, precise information is scarce on the effects of the various soil acidity factors and their interactions on yields and foliar composition of soybeans growing on Ultisols and Oxisols under humid tropical conditions.

This paper presents the results of field experiments conducted on three typical Ultisols and one Oxisol in Puerto Rico, in which the effects of the various soil acidity factors on yields and leaf composition of soybeans were determined.

\section{MATERIALS AND METHODS}

Three Uitisols: Corozal soil and subsoil (Aquic Tropudults), Humatas (Typic Tropohumults), and one Oxisol, Coto (Tropeptic Haplorthox), were used in these field experiments. The experiments consisted of 30 plots each on Corozal soil, and subsoil, 60 on Humatas, and 40 on Coto. All plots were $4 \times 4 \mathrm{~m}$ arranged in a completely randomized design and surrounded by ditches to avoid runoff from one plot to another.

Increments of finely ground hydrated lime were added to the different plots to provide a wide range of soil $\mathrm{pH}$, and exchangeable $\mathrm{Al}, \mathrm{Mn}$, and $\mathrm{Ca}+\mathrm{Mg}$. The liming material was thoroughly mixed with the upper $20 \mathrm{~cm}$ of soil in all plots.

Six months later, the soil in all plots was sampled by taking 10 borings from 0 - to $15-\mathrm{cm}$ depth in each plot. The samples were air dried 
and passed through a 10-mesh screen. Exchangeable bases were extracted with normal neutral ammonium acetate and exchangeable $\mathrm{Ca}$ and $\mathrm{Mg}$ determined by the Versenate titration method (7). Exchangeable $\mathrm{K}$ was determined by flame photometry. Exchangeable Al was extracted with normal $\mathrm{KCl}$ and determined by the double titration method (11). Soil reaction was measured with a glass electrode $\mathrm{pH}$ meter, using a saturated paste.

Soybeans of the Hardee variety were planted $8 \mathrm{~cm}$ apart in rows 45 $\mathrm{cm}$ apart in June 1971 and harvested about 4 months later. All plots were fertilized at planting with $60 \mathrm{~kg} / \mathrm{ha}$ of $\mathrm{P}_{2} \mathrm{O}_{5}, 100 \mathrm{~kg} / \mathrm{ha}$ of $\mathrm{K}_{2} \mathrm{O}, 30$ $\mathrm{kg} / \mathrm{ha}$ of $\mathrm{Mg}$ and $30 \mathrm{~kg} / \mathrm{ha}$ of a complete minor element mixture. Insects were controlled by periodically spraying with Diazinon. ${ }^{4}$

The experiments on Corozal and Humatas were not irrigated, but that on Coto was irrigated as required to maintain good growth.

Two months after planting, the fourth and fifth pair of leaves of plants growing in the center row of each plot were sampled and analyzed for $\mathrm{Ca}$ and $\mathrm{Mg}$ by the Versanate method, $\mathrm{K}$ by flame photometry, $\mathrm{Mn}$ as permanganate after oxidation with periodate, $\mathrm{P}$ colorimetrically, and $\mathrm{N}$ by the Kjeldahl method.

Yields of dry (14\% moisture) clean beans were determined in all plots and were related through regression analysis to the various soil acidity factors.

\section{RESULTS AND DISCUSSION}

\section{COROZAL CLAY SOIL (AQUIC TROPUDULTS)}

Al saturation ${ }^{5}$ of the soil varied from 0 to over $60 \%, \mathrm{pH}$ from 4.3 to 5.6 , exchangeable Al from .29 to $8.92 \mathrm{meq} / 100 \mathrm{~g}$ of soil and the Al/base ratio from .03 to 2.03 (table 1). Maximum yield of $2,081 \mathrm{~kg} / \mathrm{ha}$ was obtained at the highest average $\mathrm{pH}$ of 5.60 corresponding to the lowest percent $\mathrm{Al}$ saturation range of $0-9$. When $\mathrm{pH}$ was decreased to 5.0 and $\mathrm{Al}$ saturation increased to the 10 to $19 \%$ range, $63 \%$ of maximum yield was recorded. When $\mathrm{pH}$ decreased to 4.80 and $\mathrm{Al}$ saturation percentage reached the 20-29 range, only $28 \%$ of maximum yield was recorded. This drastic reduction in yield at a low Al saturation percentage indicated that soybeans are quite sensitive to $\mathrm{Al}$.

Soil acidity factors strongly affected some of the foliar constituents of

${ }^{4}$ Trade names are used in this publication solely for the purpose of providing specific information. Mention of a trade name does not constitute a guarantee or warranty of equipment or materials by the Agricultural Experiment Station of the University of Puerto Rico or an endorsement over other equipment or materials not mentioned.

${ }^{5} \mathrm{CEC}$ by sum of cations. 
TABLE 1. - Effect of soil acidity factors on yield and foliar composition of Hardee variety soybeans grown on a Corozal soil

\begin{tabular}{|c|c|c|c|c|c|c|c|c|c|c|c|c|}
\hline \multirow{2}{*}{$\mathrm{pH}$} & \multicolumn{3}{|c|}{ Soil properties } & \multirow{2}{*}{ Yield } & \multicolumn{7}{|c|}{ Foliar composition } & \multirow[b]{2}{*}{ Nodules } \\
\hline & $\begin{array}{l}\text { Al satura- } \\
\text { tion }\end{array}$ & $\begin{array}{c}\text { Exchange- } \\
\text { able Al }\end{array}$ & Al bases & & $\mathrm{Ca}$ & $\mathrm{Mg}$ & $\mathrm{N}$ & $\mathrm{P}$ & $\mathrm{K}$ & $\mathrm{Mn}$ & $\mathrm{Ca} / \mathrm{Mn}$ & \\
\hline & $\%$ & Meq/100 g & & Kg/ha & $\%$ & $\%$ & $\%$ & $\%$ & $\%$ & $P / m$ & & No./plant \\
\hline 5.60 & $0-9$ & 0.29 & 0.03 & 2,081 & 1.71 & 0.23 & 4.49 & 0.30 & 1.63 & 152 & 113 & 75 \\
\hline 5.00 & $10-19$ & 1.41 & .13 & 1,311 & 1.49 & .20 & 3.47 & .26 & 1.56 & 152 & 98 & 62 \\
\hline 4.80 & $20-29$ & 3.21 & .36 & 585 & 1.39 & .16 & 3.35 & .25 & 1.54 & 150 & 91 & 44 \\
\hline 4.70 & $30-39$ & 3.90 & .49 & 558 & 1.26 & .16 & 3.03 & .24 & 1.48 & 152 & 83 & 13 \\
\hline 4.60 & $40-49$ & 5.28 & .78 & 532 & 1.02 & .14 & 2.81 & .24 & 1.47 & 152 & 67 & 4 \\
\hline 4.50 & $50-59$ & 7.50 & 1.82 & 64 & .79 & .17 & 2.17 & .21 & 2.09 & 151 & 52 & 0 \\
\hline 4.30 & $60+$ & 8.92 & 2.03 & 62 & .80 & .17 & 2.16 & .26 & 2.10 & 150 & 53 & 0 \\
\hline
\end{tabular}

Rainfall-cm: June, 4.1; July, 13.0; Aug., 11.5; Sept. 8.8. Total = 37.4. 
soybeans but did not affect others. The $\mathrm{Ca}$ and $\mathrm{N}$ contents decreased as percent $\mathrm{Al}$ saturation of the soil increased, as $\mathrm{pH}$ decreased, and as the $\mathrm{Al} / \mathrm{base}$ ratio increased. There was a drastic reduction in nodulation from 75 nodules per plant at the lowest Al saturation to no nodules when percent $\mathrm{Al}$ saturation reached the 50 to $59 \%$ range. Probably the activity of the $\mathrm{N}$-fixing bacteria was curtailed at high $\mathrm{Al}$ concentrations. The $\mathrm{Ca} / \mathrm{Mn}$ ratio in the leaves decreased sharply with increasing $\mathrm{Al}$ saturation of the soil. This was caused largely by a decrease in $\mathrm{Ca}$

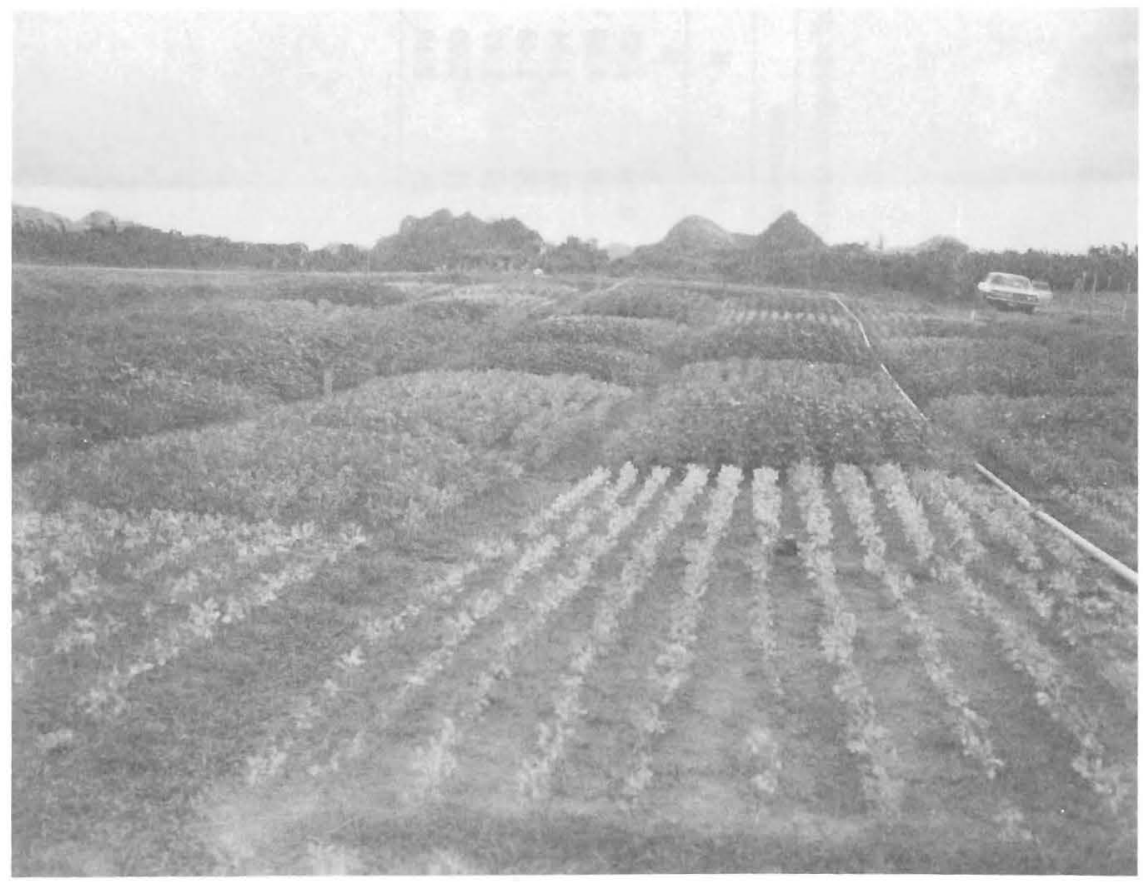

FIG. 1. - Partial view of the Corozal clay soil site. Plot in foreground has a $\mathrm{pH}$ of 4.0 and an $\mathrm{Al}$ saturation of $68 \%$, while the one on the background has a $\mathrm{pH}$ of 5.3 and no exchangeable Al.

content of the leaves with a fairly constant Mn content. Soybean plants in unlimed plots were yellowish, unlike the deep green color of plants in the heavily limed plots (fig. 1). This soil is relatively low in exchangeable Mn but high in exchangeable Al.

Figure 2 shows that there was a significant correlation between soil $\mathrm{pH}$ and soybean yields. Essentially no yields were produced when the $\mathrm{pH}$ decreased to about 4.3 , whereas yields were maximum at about $\mathrm{pH}$ 5.6. Figure 3 shows the close correlation between soybean yields and percent $\mathrm{Al}$ saturation of the soil. About $86 \%$ of the variation in yield 
could be attributed to this soil acidity factor. Similarly, the Al/base ratio was significantly correlated to soybean yields (fig. 4).

Figure 5 shows the close positive correlation between $\mathrm{N}$ content of the soybean leaves and yields. $\mathrm{N}$ content of $5 \%$ at the prebloom stage was associated with maximum yield. This variation in $\mathrm{N}$ content of the leaves and, thus, in yields was associated with soil pH (fig. 6).

Figure 7 shows that the $\mathrm{Ca}$ content of the leaves was positively correlated with soybean yields, but the correlation was not as close as with $\mathrm{N}$, possibly because $\mathrm{N}$ uptake is higher than that of $\mathrm{Ca}$.

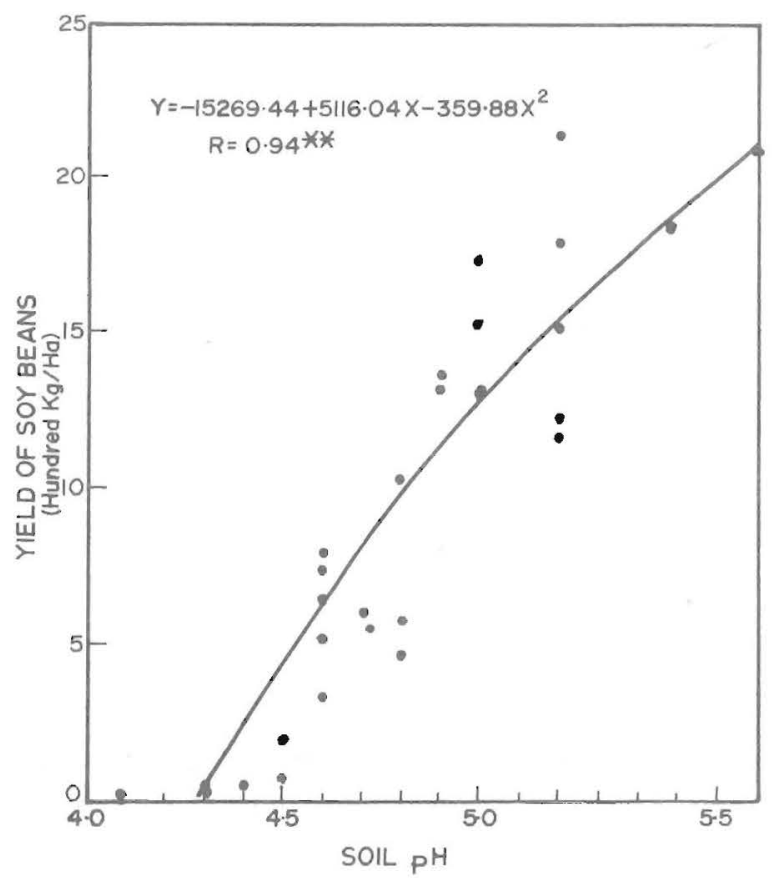

Fig. 2. - Influence of the Corozal clay soil pH on the yield of soybean.

The variation in Ca content of the leaves as affected by $\mathrm{pH}$ (fig. 8) and percent $\mathrm{Al}$ saturation (fig. 9) seemed to indicate that Al toxicity is intimately related to reduced $\mathrm{Ca}$ uptake $(4,5)$. A Ca content of about $2 \%$ was associated with maximum yields, whereas almost no yield could be expected if $\mathrm{Ca}$ content of the leaves was less than about $0.6 \%$.

\section{COROZAL CLAY SUBSOIL (AQUIC TROPUDULTS)}

The average $\mathrm{pH}$ values for this soil were similar to those of the Corozal soil, ranging from 5.50 to 4.15 (table 2) but total exchangeable Al was somewhat lower than in Corozal soil at corresponding percent $\mathrm{Al}$ saturation ranges, because of a lower cation exchange of the subsoil. 
Similarly, the Al/base ratios were lower, especially at the very low $\mathrm{pH}$ levels.

Soybean yields decreased as the percent $\mathrm{Al}$ saturation and the $\mathrm{Al} /$ base ratio increased or as $\mathrm{pH}$ decreased. However, the decrease in yield with increasing acidity was more drastic in this soil than in the Corozal soil. For example, at $\mathrm{pH} 4.95$, corresponding to 10 to $19 \% \mathrm{Al}$ saturation, only $47 \%$ of the maximum yield was produced, whereas at $\mathrm{pH} 4.6$ (30 to $39 \% \mathrm{Al}$ saturation), yields were only $23 \%$ of maximum.

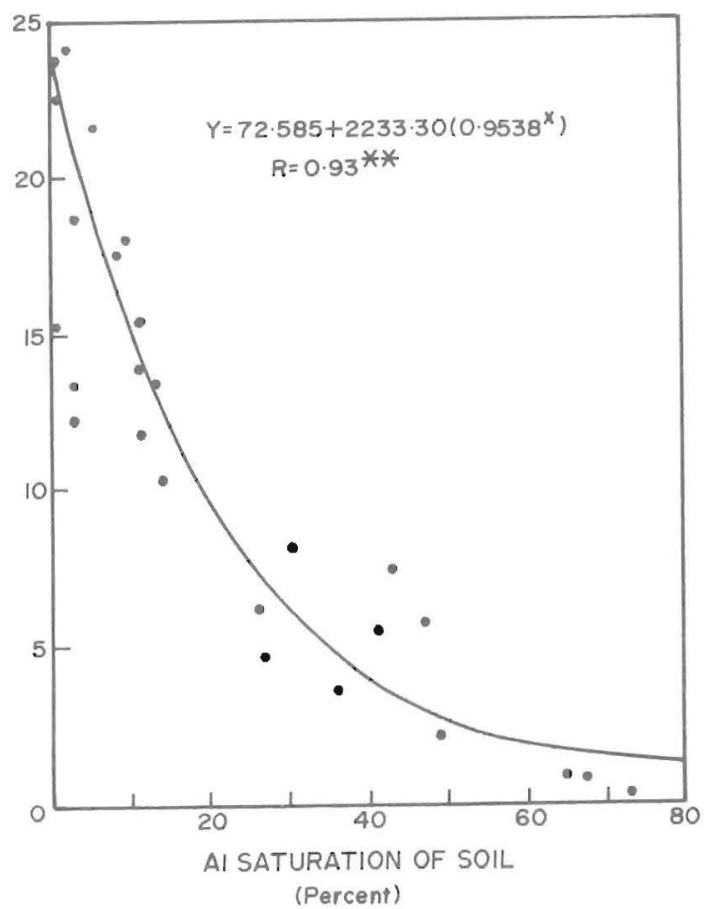

FIG. 3.-Influence of the Al saturation percentage of Corozal clay soil on soybean yields.

Surprisingly, the highest yield of $2,474 \mathrm{~kg} / \mathrm{ha}$, obtained on this subsoil at optimum $\mathrm{pH}$ level (table 2) was about $400 \mathrm{~kg} / \mathrm{ha}$ higher than the best yield obtained on the Corozal soil (table 1).

As in the experiment on Corozal soil, the $\mathrm{N}$ and $\mathrm{Ca}$ content of the leaves varied widely with variation in soil acidity factors. Both the $\mathrm{Ca}$ and the $\mathrm{N}$ contents at corresponding $\mathrm{pHs}$ and $\mathrm{Al}$ and $\mathrm{Al} /$ base ratios were similar in both soil and subsoil. The highest yields obtained $(2,474 \mathrm{~kg} / \mathrm{ha})$ were associated with leaf contents of $4.75 \% \mathrm{~N}$ and $1.63 \%$ $\mathrm{Ca}$. The other foliar constituents were not affected by variations in soil 
acidity factors. The $\mathrm{Ca} / \mathrm{Mn}$ ratio varied from 105 at the lowest $\mathrm{Al}$ saturation to 45 at the $60 \%$ level.

An average of 106 nodules per plant was obtained with only 0.27 meq exchangeable $\mathrm{Al} / 100 \mathrm{~g}$ of soil as compared with no nodules when $\mathrm{Al}$ saturation exceeded $60 \%$ at $\mathrm{pH} 4.15$ and at $1.70 \mathrm{Al} / \mathrm{base}$ ratio.

Regression analysis of the data showed close correlations between soybean yields and the various soil-acidity factors. Figure 10 shows a close correlation between soil $\mathrm{pH}$ and soybean yields with maximum

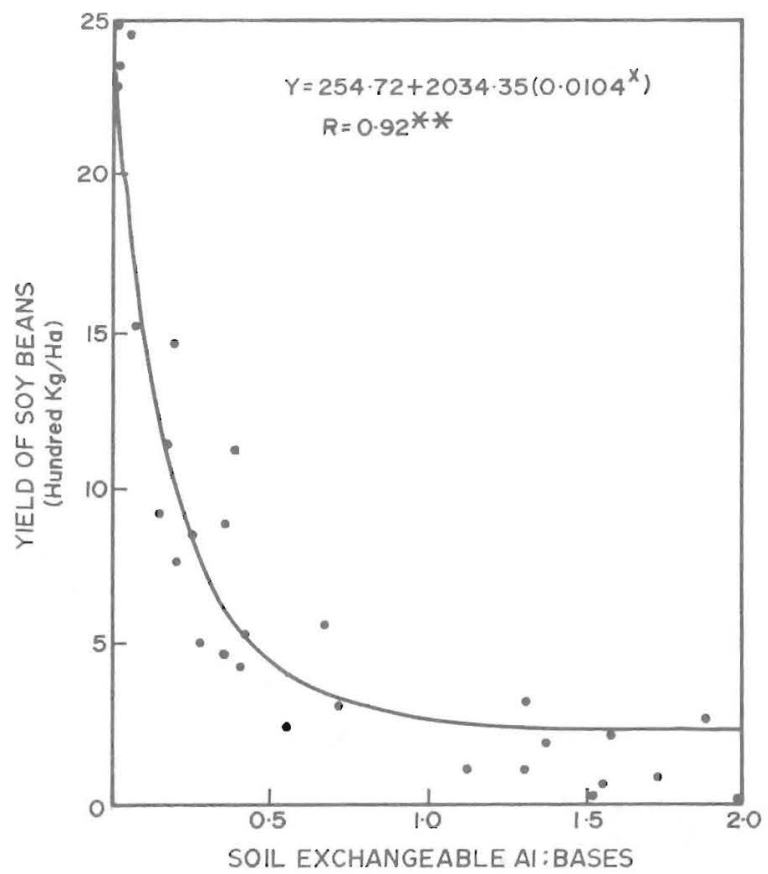

FIG. 4.- Influence of the Al/base ratio of Corozal clay soil on soybean yields.

yield attained at about $\mathrm{pH} 5.5$, a level at which soluble $\mathrm{Al}$ in the soil would be precipitated.

A high correlation was obtained between percent $\mathrm{Al}$ saturation of the soil and soybean yields (fig. 11) with $90 \%$ of the variation in yields explained by this soil acidity factor. Essentially no yields were produced at $60 \% \mathrm{Al}$ saturation, while $2,500 \mathrm{~kg} / \mathrm{ha}$ were produced at zero percent $\mathrm{Al}$ saturation. Figure 12 shows that when the $\mathrm{Al} /$ base ratio approached 1 , yield was zero, whereas when the $\mathrm{Al} /$ base ratio approached zero $2,000 \mathrm{~kg} / \mathrm{ha}$ soybeans were produced. 


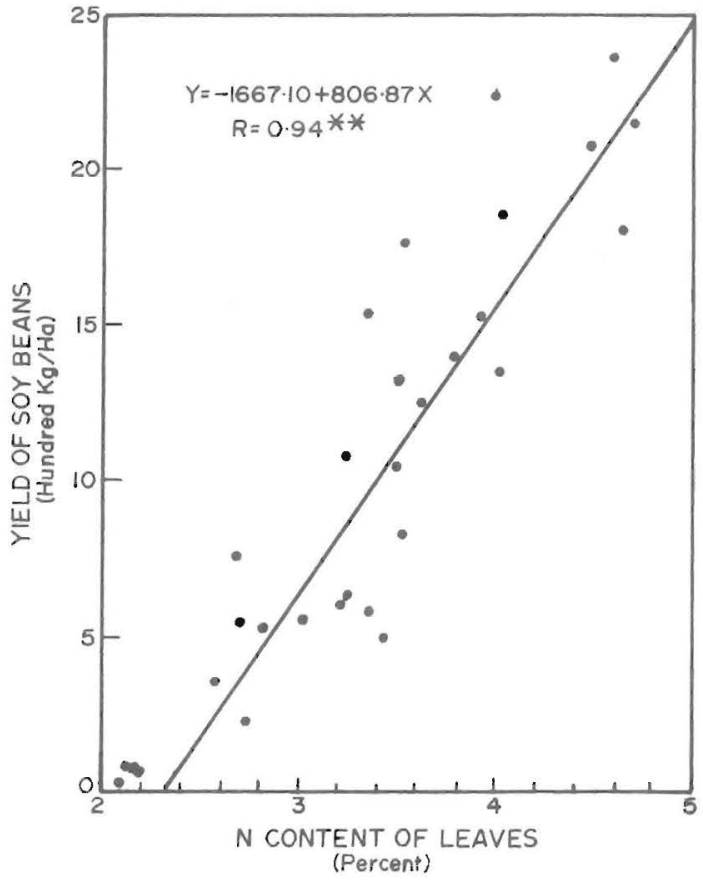

FIG. 5.-Relationship between grain yields and the $N$ content of the leaves of soybean grown on Corozal clay soil.

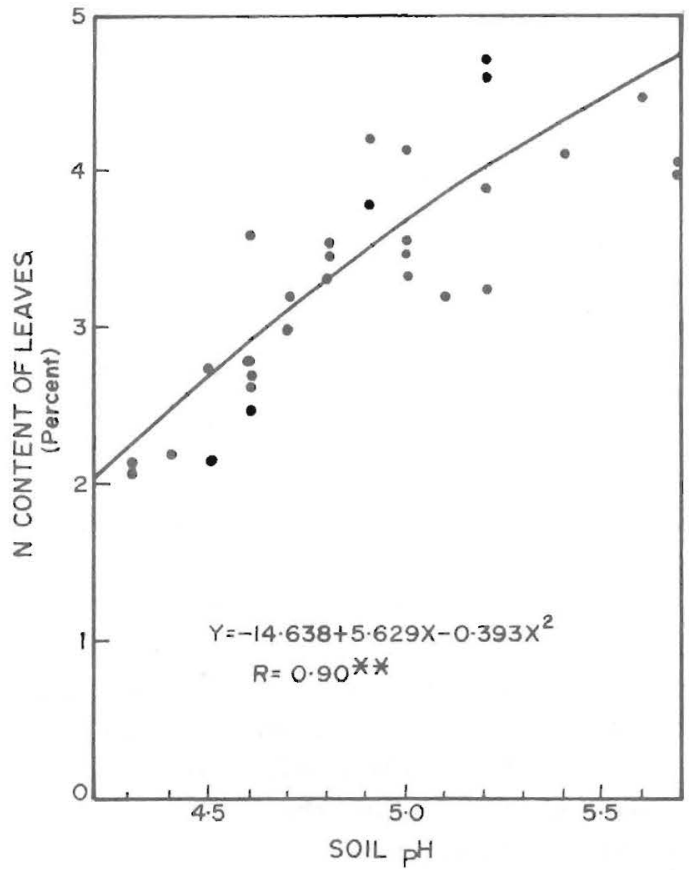

Fra. 6. - Influence of the Corozal clay soil $\mathrm{pH}$ on the $\mathrm{N}$ content of the soybean leaves. 


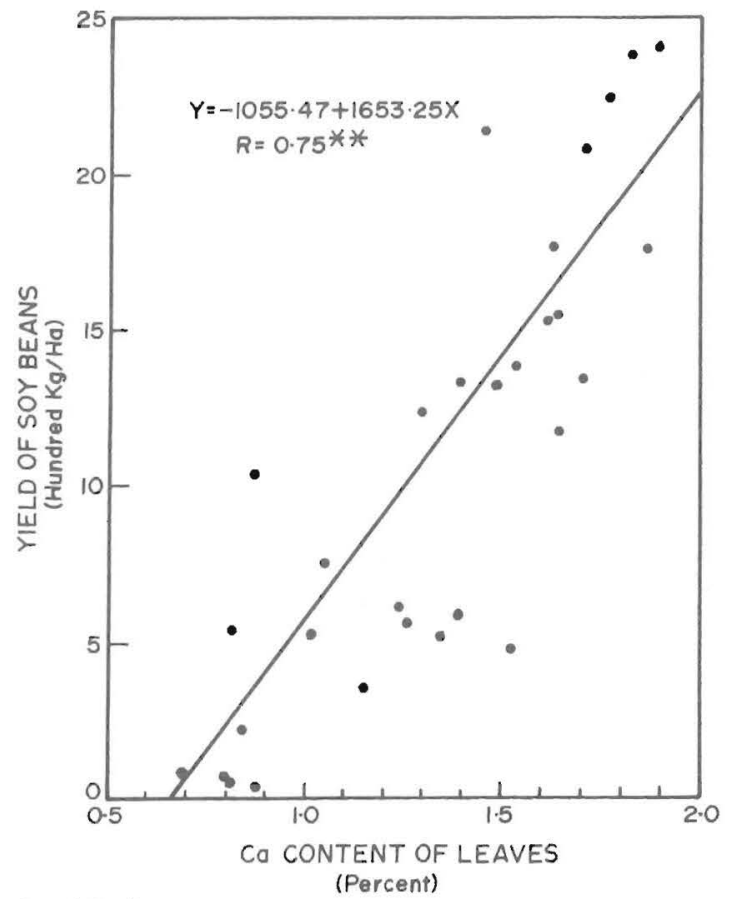

FIG. 7.-Relationship between grain yields and the Ca content of the leaves of soybean grown on Corozal clay soil.

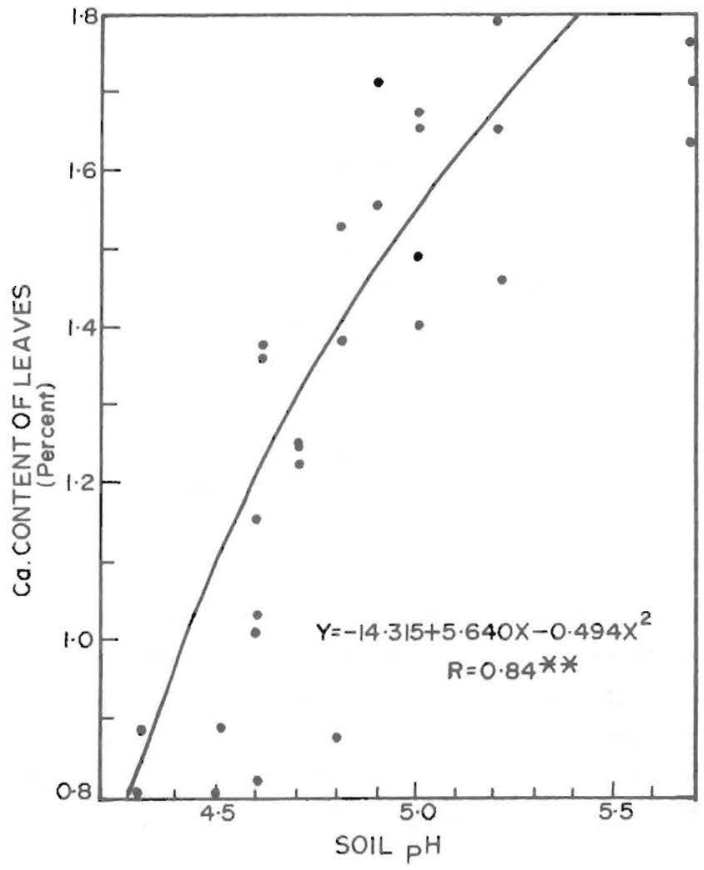

FIG. 8. - Influence of the Corozal clay soil pH on the Ca content of the soybean leaves. 


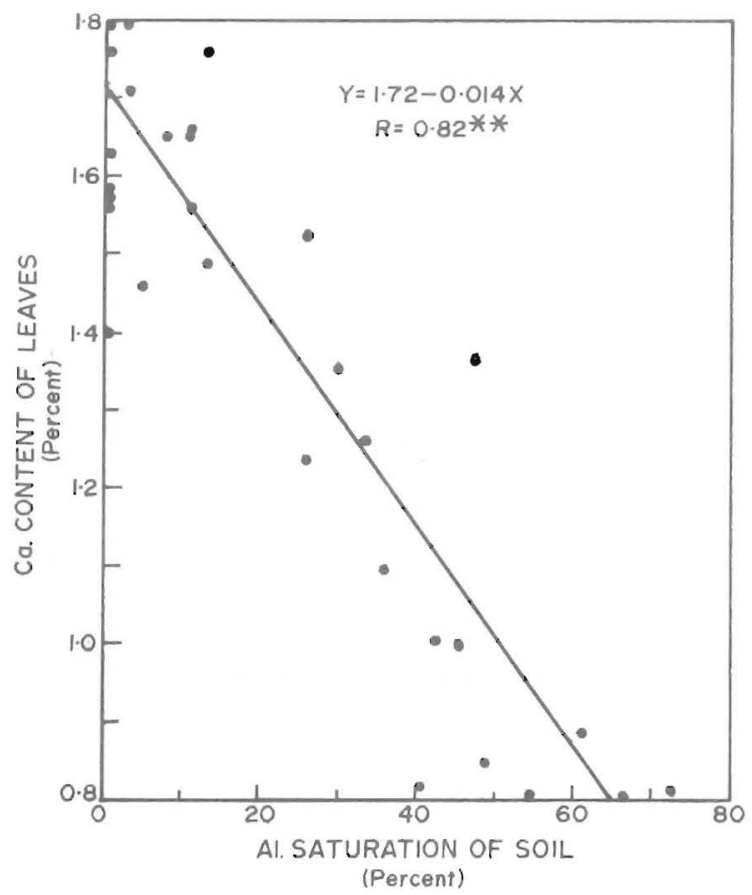

FIG. 9. - Influence of the percent Al saturation of Corozal clay soil of the Ca content of soybean leaves.

On Corozal soil, $\mathrm{N}$ content of the leaves was highly correlated with yield (fig.13). A $\mathrm{N}$ content of $5 \%$ was associated with maximum yield. Calcium content of the soybeans at the prebloom stage was positively correlated with yields (fig. 14). Soil $\mathrm{pH}$ had a significant effect on Ca and $\mathrm{N}$ contents of the leaves (figs. 15 and 16). For example, at pH 4.0 the $\mathrm{Ca}$ content of the leaves was $0.7 \%$ and $\mathrm{N}$ contents about 1.3, whereas at pH. 5.5, Ca content was $1.70 \%$ and $\mathrm{N}$ content was $4.75 \%$

Since Al saturation depends largely on soil $\mathrm{pH}$, it also had a significant effect on Ca content of the leaves (fig. 17).

\section{HUMATAS CLAY (TYPIC TROPOHUMULTS)}

Soybean yields (table 3 ) in this soil were relatively low, probably due to the constant strong winds blowing on this exposed site, excessive rainfall, and insect damage, despite periodic spraying.

This soil had lower $\mathrm{pH}$ 's and higher percentages of $\mathrm{Al}$ saturations (table 3) than the two previously discussed soils. At $\mathrm{pH} 3.9$, for example, the $\mathrm{Al}$ saturation percentage was over 70 and the $\mathrm{Al} / \mathrm{base}$ ratio was 3.33 .

Data in table 3 show that at $\mathrm{pH} 5.6$, this soil had a cation exchange 
TABLE 2. - Effect of soil acidity factors on yield and foliar composition of Hardee variety soybeans grown on a Corozal subsoil

\begin{tabular}{|c|c|c|c|c|c|c|c|c|c|c|c|c|}
\hline \multirow{2}{*}{$\mathrm{pH}$} & \multicolumn{3}{|c|}{ Soil properties } & \multirow{2}{*}{ Yield } & \multicolumn{7}{|c|}{ Foliar composition } & \multirow[b]{2}{*}{ Nodules } \\
\hline & $\begin{array}{l}\text { Aluminum } \\
\text { saturation }\end{array}$ & $\begin{array}{c}\text { Exchange- } \\
\text { able Al }\end{array}$ & $\begin{array}{c}\mathrm{Al} / \\
\text { bases }\end{array}$ & & $\mathrm{Ca}$ & $\mathrm{Mg}$ & $\mathrm{N}$ & $\mathrm{P}$ & $\mathrm{K}$ & $\mathrm{Mn}$ & $\mathrm{Ca} / \mathrm{Mn}$ & \\
\hline & $\%$ & Meq/100 g & & $K g / h a$ & $\%$ & $\%$ & $\%$ & $\%$ & $\%$ & $P / m$ & & No./plant \\
\hline 5.50 & $0-9$ & 0.27 & 0.03 & 2,474 & 1.63 & 0.13 & 4.75 & 0.28 & 1.77 & 155 & 105 & 106 \\
\hline 4.95 & $10-19$ & 1.63 & .17 & 1,171 & 1.39 & .14 & 4.09 & .25 & 1.84 & 152 & 91 & 36 \\
\hline 4.70 & $20-29$ & 2.74 & .35 & 700 & 1.19 & .13 & 2.88 & .20 & 1.40 & 152 & 78 & 21 \\
\hline 4.60 & $30-39$ & 3.42 & .55 & 571 & 1.00 & .16 & 2.56 & .21 & 1.75 & 151 & 66 & 10 \\
\hline 4.50 & $40-49$ & 4.38 & .69 & 296 & 1.02 & .16 & 2.54 & .21 & 1.58 & 152 & 67 & 6 \\
\hline 4.35 & $50-59$ & 6.07 & 1.27 & 200 & .69 & .19 & 2.24 & .22 & 1.63 & 152 & 45 & 1 \\
\hline 4.15 & $60+$ & 6.94 & 1.70 & 86 & .69 & .17 & 2.04 & .24 & 1.84 & 152 & 45 & 0 \\
\hline
\end{tabular}

Rainfall-cm: June, 4.1; July, 13.0; Aug., 11.5; Sept., 8.8. Total = 37.4. 


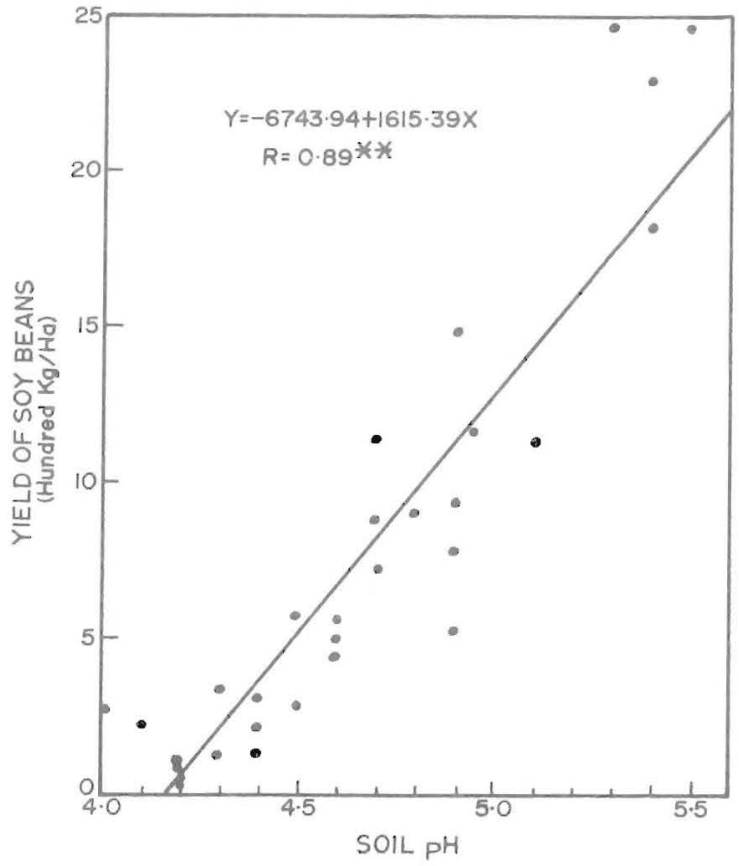

FIG. 10. - Influence of the Corozal clay soil pH on soybean yields.

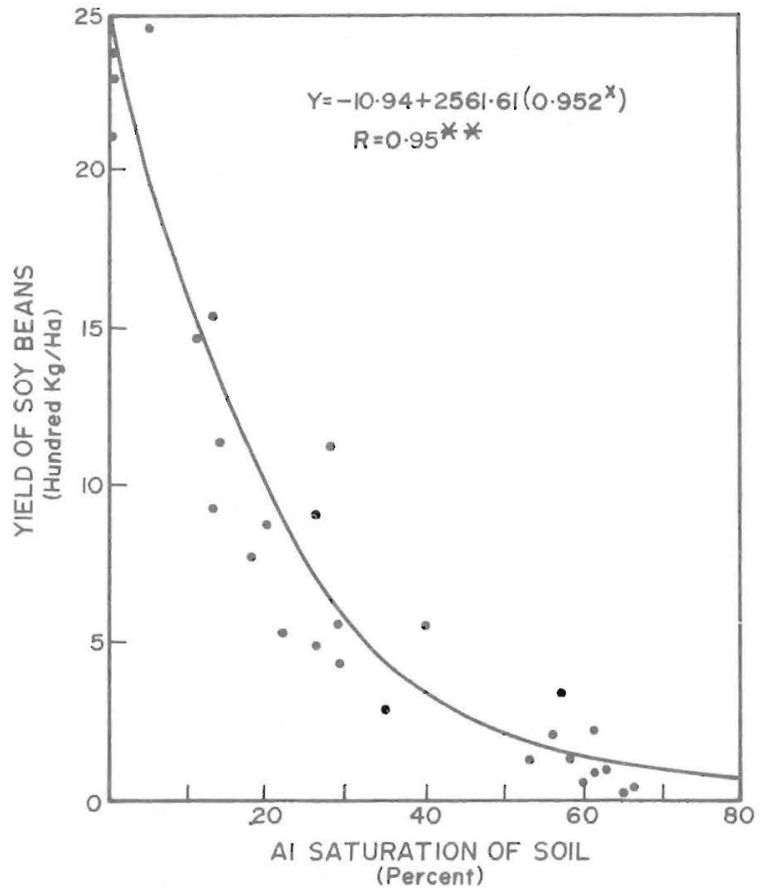

FIG. 11.-Influence of the percent Al saturation of the Corozal clay subsoil on soybean yields. 


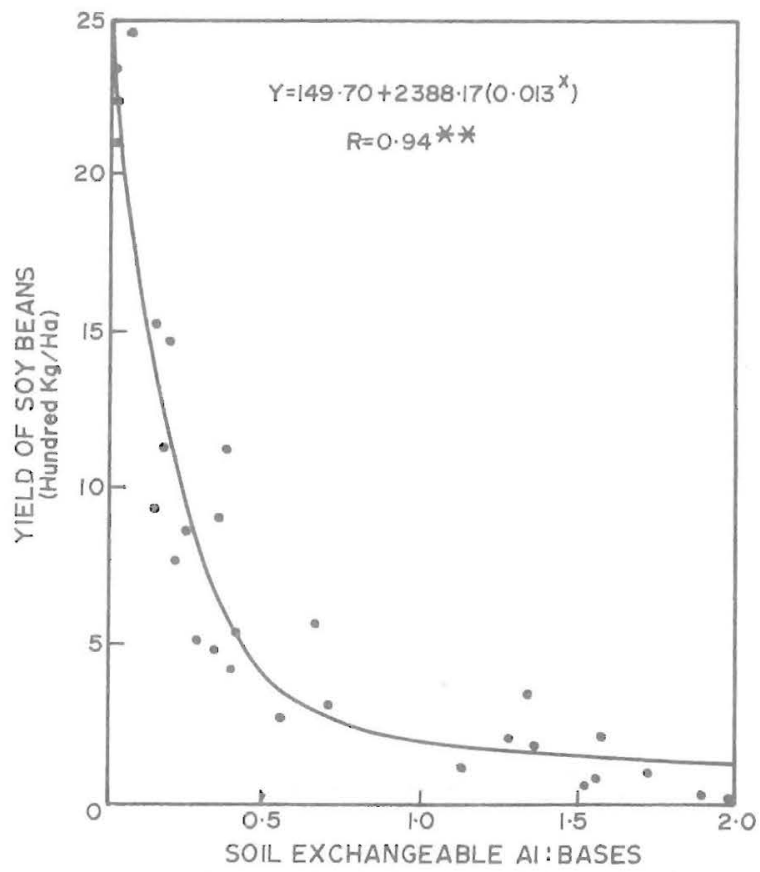

FIG. 12. - Influence of the Al/base ratio of the Corozal clay subsoil on soybean yields.

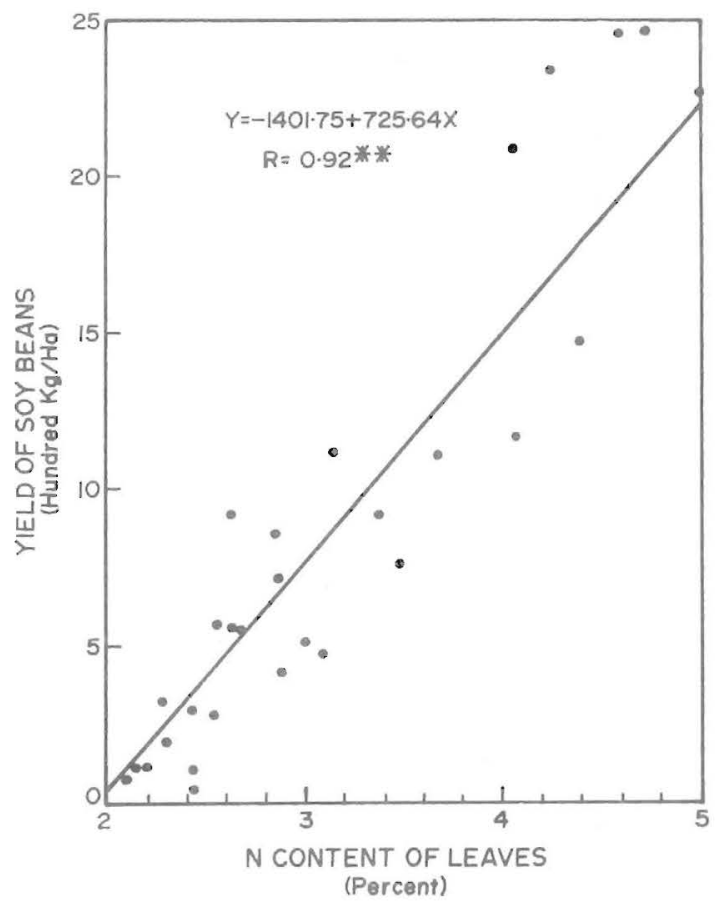

FIG. 13. - Relationship between grain yields and the $\mathrm{N}$ content of soybean leaves grown on Corozal clay subsoil. 


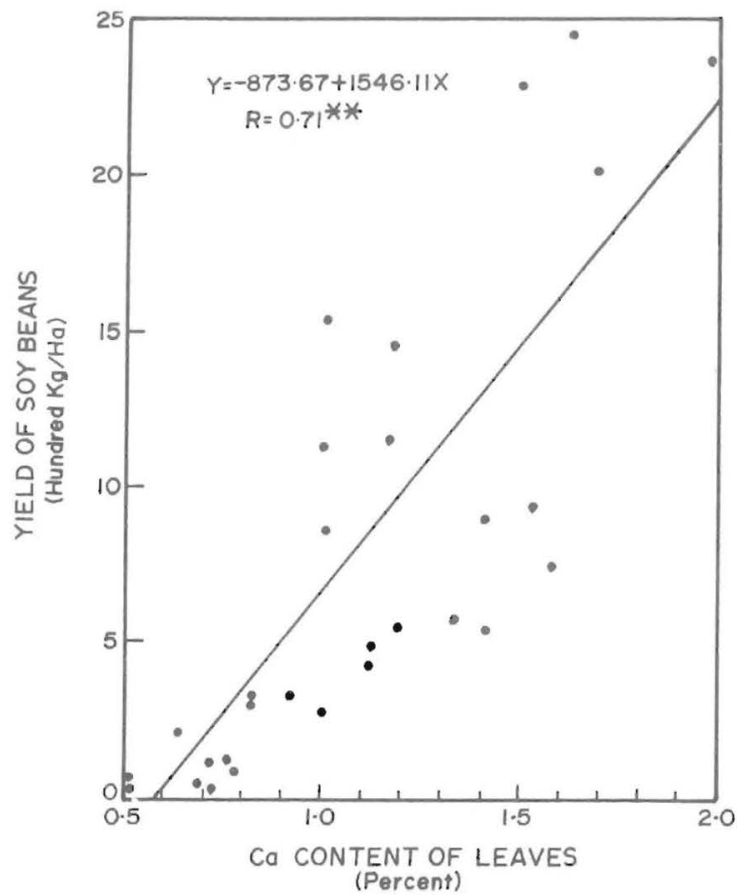

FIG. 14.-Relationship between grain yields and the Ca content of soybean leaves grown on Corozal clay subsoil.

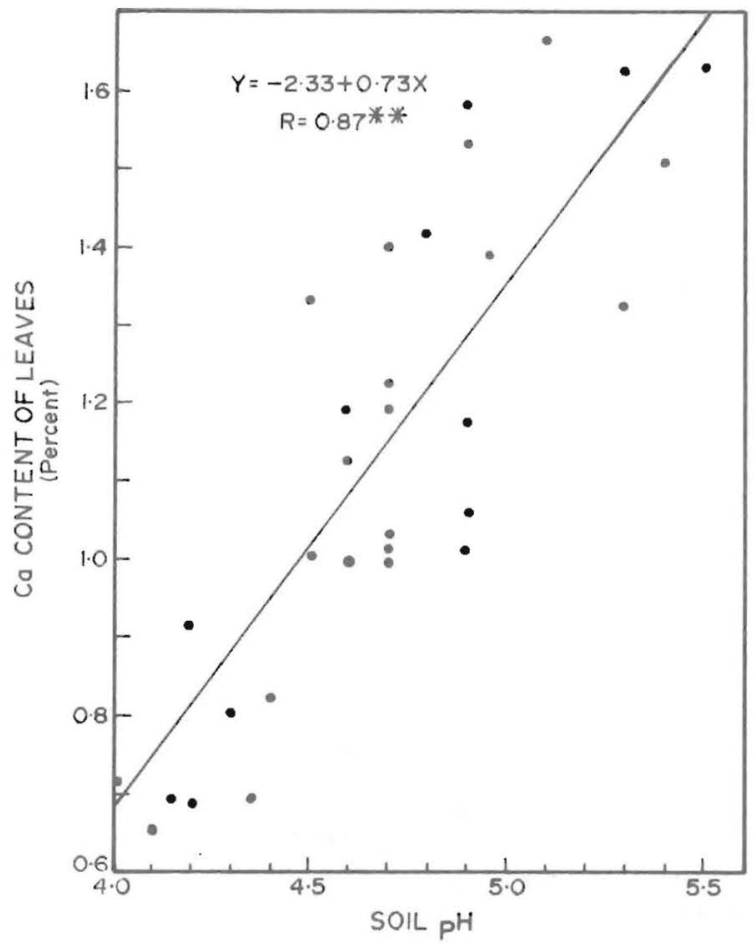

Fig. 15. - Influence of the Corozal subsoil $\mathrm{pH}$ on the Ca content of soybean leaves. 


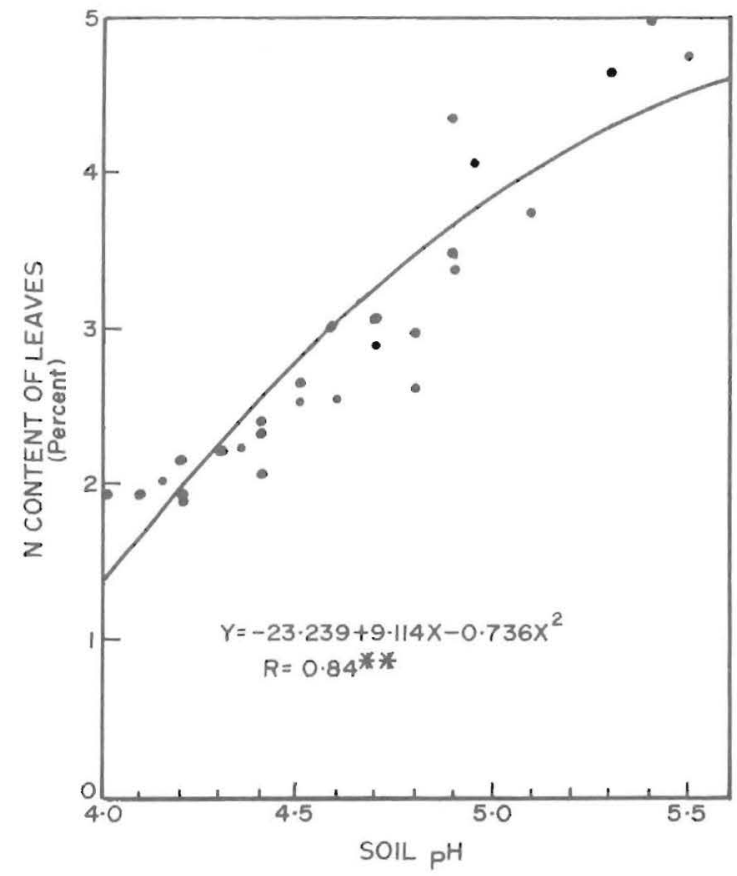

FIG. 16. - Influence of the Corozal subsoil pH on the $\mathrm{N}$ content of soybean leaves.

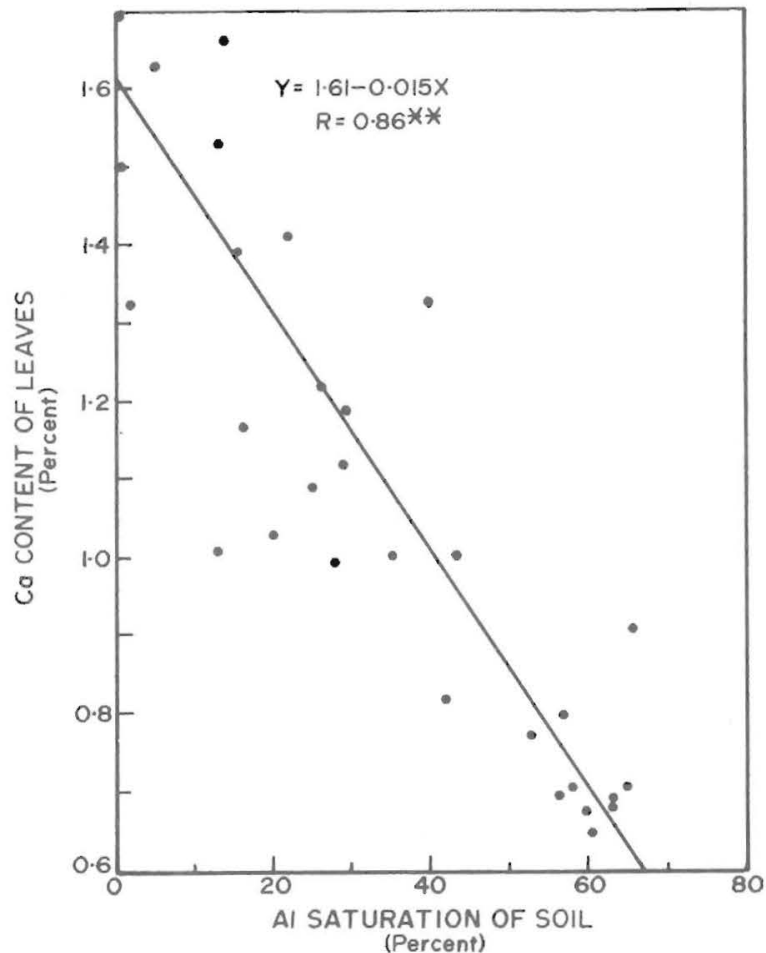

FIG. 17. - Influence of the percent Al saturation of the Corozal subsoil on the $\mathrm{Ca}$ content of the soybean leaves. 
TABLE 3.-Effect of soil acidity factors on yield and foliar composition of Hardee variety soybeans grown on Humatas soil at Orocovis

\begin{tabular}{|c|c|c|c|c|c|c|c|c|c|c|c|}
\hline \multirow{2}{*}{$\mathrm{pH}$} & \multicolumn{3}{|c|}{ Soil properties } & \multirow{2}{*}{ Yield } & \multicolumn{7}{|c|}{ Foliar composition } \\
\hline & $\begin{array}{l}\text { Al satura- } \\
\text { tion }\end{array}$ & $\begin{array}{l}\text { Exchangea- } \\
\text { ble Al }\end{array}$ & $\begin{array}{c}\mathrm{Al} / \\
\text { bases }\end{array}$ & & $\mathrm{Ca}$ & $\mathrm{Mg}$ & $\mathrm{N}$ & $P$ & K & $\mathrm{Mn}$ & $\mathrm{Ca} / \mathrm{Mn}$ \\
\hline & $\%$ & Meq/100 g & & Kg/ha & $\%$ & $\%$ & $\%$ & $\%$ & $\%$ & $P / m$ & \\
\hline 5.60 & $0-9$ & 0.25 & 0.02 & 915 & 1.78 & 0.24 & 5.14 & 0.21 & 2.19 & 60 & 297 \\
\hline 4.90 & $10-19$ & 1.39 & .17 & 906 & 1.63 & .26 & 4.67 & .21 & 2.30 & 64 & 255 \\
\hline 4.80 & $20-29$ & 2.19 & .28 & 875 & 1.58 & .22 & 4.83 & .20 & 2.22 & 54 & 292 \\
\hline 4.60 & $30-39$ & 3.31 & .56 & 602 & 1.57 & .23 & 4.54 & .24 & 2.20 & 68 & 231 \\
\hline 4.50 & $40-49$ & 4.30 & .81 & 475 & 1.47 & .24 & 4.63 & .24 & 2.38 & 99 & 148 \\
\hline 4.40 & $50-59$ & 5.12 & 1.20 & 430 & 1.47 & .27 & 4.50 & .24 & 2.40 & 120 & 122 \\
\hline 4.20 & $60-69$ & 6.09 & 1.84 & 392 & 1.42 & .27 & 4.37 & .24 & 2.33 & 105 & 135 \\
\hline 3.90 & $70+$ & 7.26 & 3.33 & 61 & 1.04 & .25 & 4.07 & .26 & 2.50 & 125 & 83 \\
\hline
\end{tabular}

Rainfall-cm: June, 13.0; July, 16.5; Aug., 33.1; Sept., 34.3. Total = 96.9.

TABLE 4. - Effect of soil acidity factors on yields and foliar composition of Hardee variety soybeans grown on Coto soil with irrigation in Isabela

\begin{tabular}{|c|c|c|c|c|c|c|c|c|c|c|c|}
\hline \multirow{2}{*}{$\mathrm{pH}$} & \multicolumn{3}{|c|}{ Soil properties } & \multirow{2}{*}{ Yield } & \multicolumn{7}{|c|}{ Foliar composition } \\
\hline & Al saturation & $\begin{array}{l}\text { Exchangea- } \\
\text { ble Al }\end{array}$ & $\begin{array}{c}\mathrm{Al} / \\
\text { bases }\end{array}$ & & $\mathrm{Ca}$ & $\mathrm{Mg}$ & $N$ & $P$ & $\mathrm{~K}$ & $\mathrm{Mn}$ & $\mathrm{Ca} / \mathrm{Mn}$ \\
\hline & $\%$ & Meq/100 g & & $\mathrm{Kg} / \mathrm{ha}$ & $\%$ & $\%$ & $\%$ & $\%$ & $\%$ & $\mathrm{P} / \mathrm{m}$ & \\
\hline 5.30 & $0-9$ & 0.23 & 0.05 & 3555 & 2.00 & 0.15 & 4.78 & 0.16 & 1.31 & 367 & 54 \\
\hline 4.70 & $10-19$ & .57 & .19 & 2997 & 1.96 & .19 & 4.84 & .18 & 1.32 & 468 & 42 \\
\hline 4.50 & $20-29$ & .82 & .33 & 2755 & 1.86 & .19 & 4.84 & .18 & 1.39 & 514 & 36 \\
\hline 4.30 & $30+$ & 1.19 & .56 & 2540 & 1.87 & .18 & 4.81 & .20 & 1.37 & 528 & 35 \\
\hline
\end{tabular}




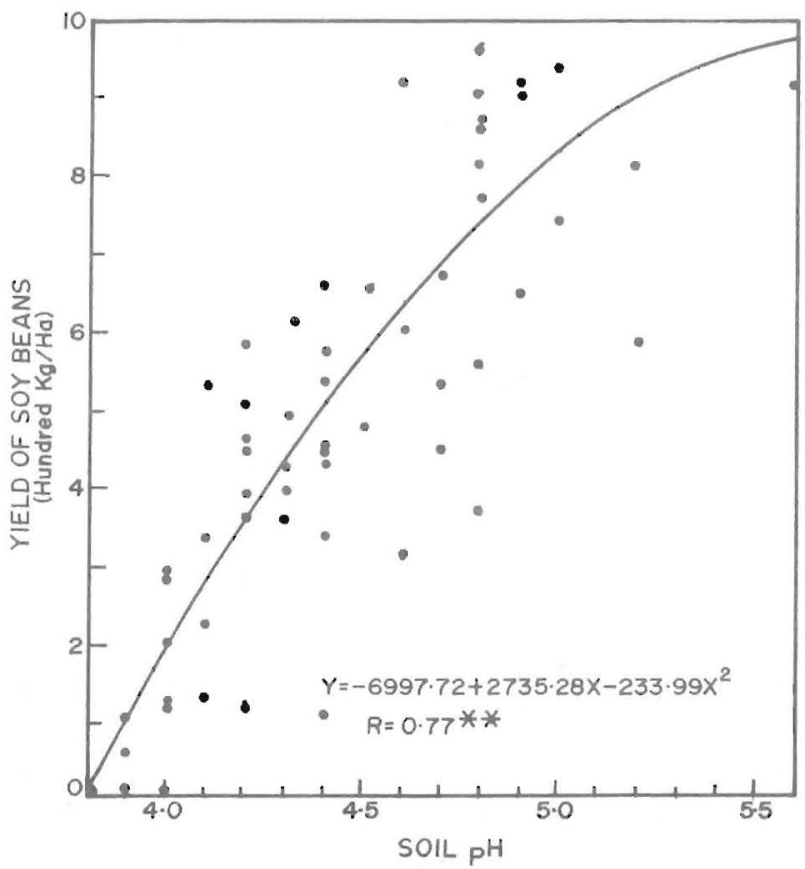

FIG. 18. - Influence of the Humatas clay $\mathrm{pH}$ on soybean yields.

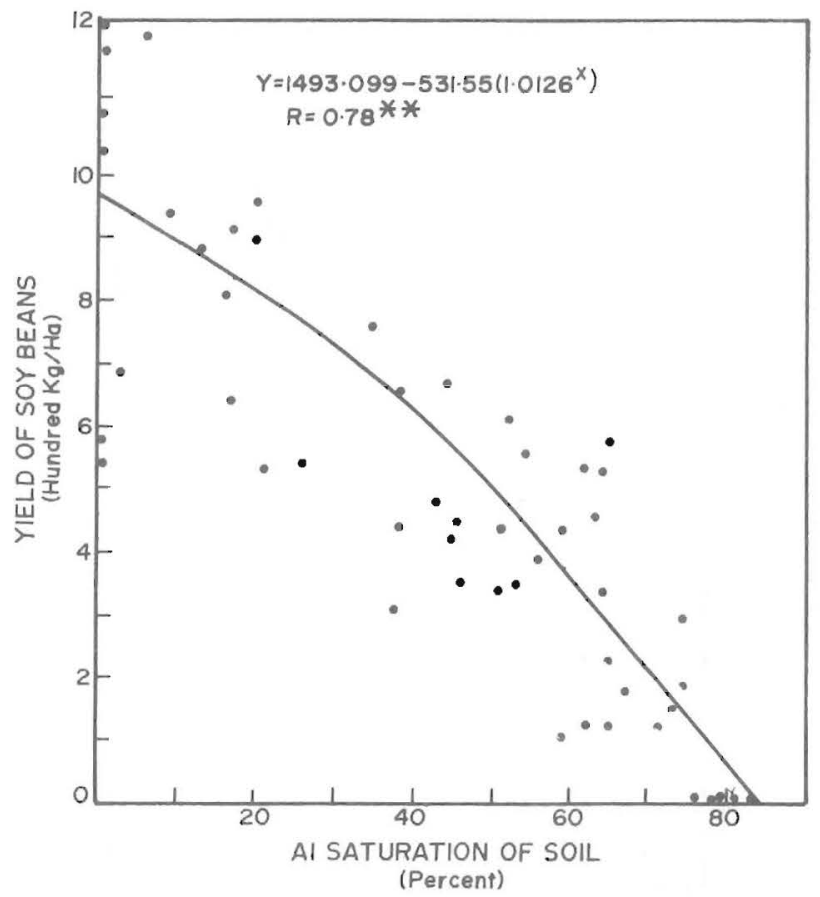

FIG. 19. - Influence of the percent Al saturation of Humatas soil on soybean yields. 


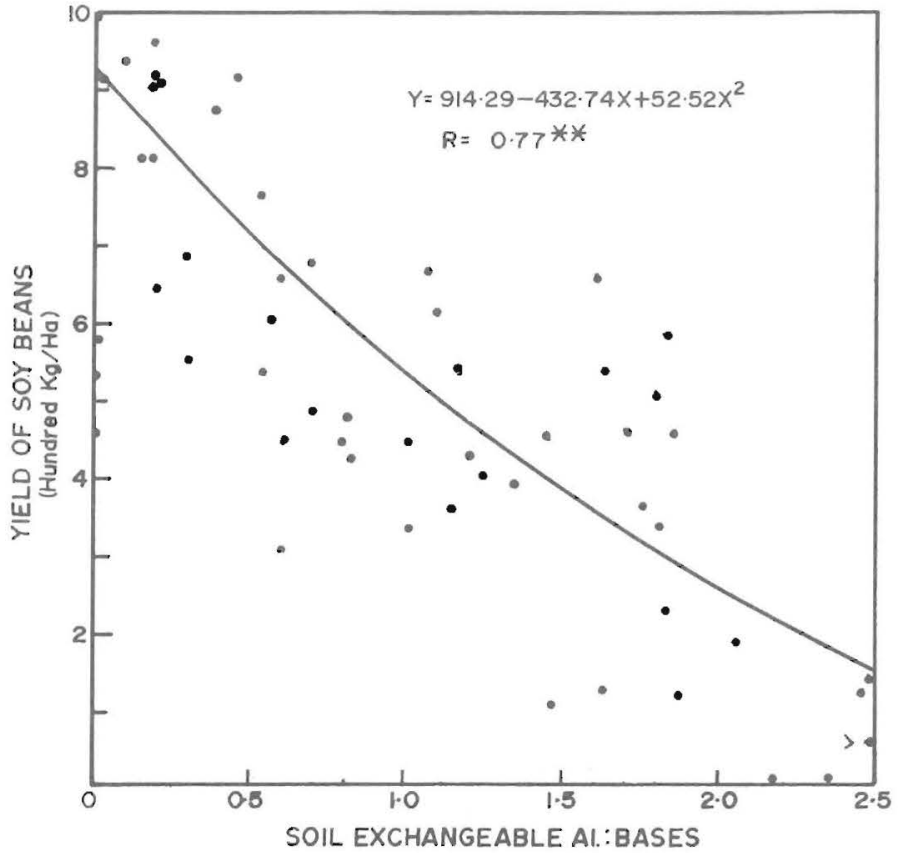

FIG. 20. - Infuence of the Al/base ratio of Humatas clay soil on soybean yields.

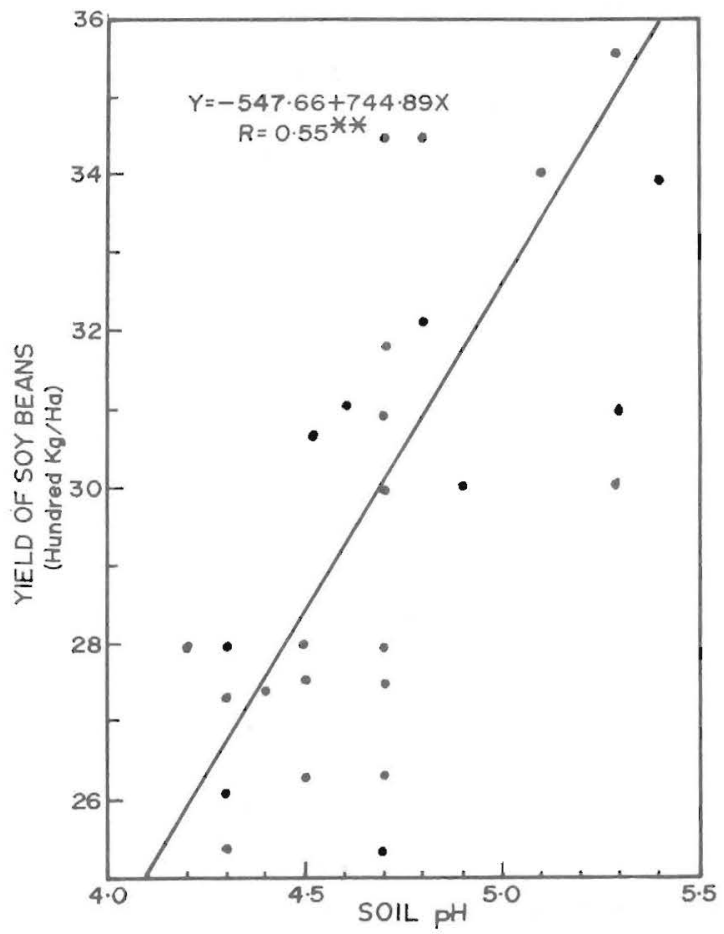

Fig. 21. - Influence of the $\mathrm{pH}$ of Coto sandy clay on soybean yields. 
capacity of $12.75 \mathrm{meq} / 100 \mathrm{~g}$, at $\mathrm{pH} 4.8,10.01 \mathrm{meq} / 100 \mathrm{~g}$ and at $\mathrm{pH} 3.9$ only $9.44 \mathrm{meq} / 100 \mathrm{~g}$, indicating a $\mathrm{pH}$ dependent charge, but much less than would be expected for a highly weathered soil like this.

There was a response to liming on this soil, although not as striking as on the Corozal soils, probably because of the other factors limiting yields. About $96 \%$ of the maximum yield was obtained at $\mathrm{pH} 4.8$ and 20 to $29 \% \mathrm{Al}$ saturation. Even at $\mathrm{pH} 4.2,43 \%$ of the maximum yield was

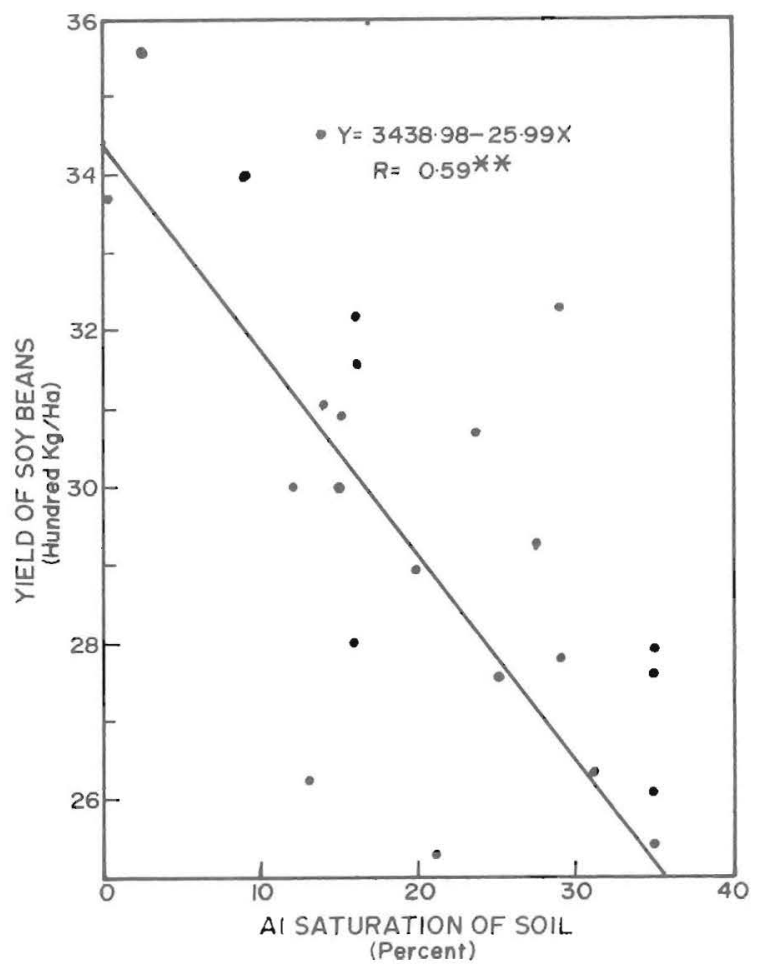

FIG. 22. - Influence of the percent Al saturation of Coto sandy clay soil on soybean yields.

obtained, while at the Corozal sites only $3 \%$ of the maximum yield was produced at this $\mathrm{pH}$ level.

The $\mathrm{Ca}, \mathrm{N}$, and $\mathrm{Mn}$ contents of the leaves and the $\mathrm{Ca} / \mathrm{Mn}$ ratio were affected by the various soil acidity factors, but not as strikingly as on the Corozal soils.

Yields increased as soil $\mathrm{pH}$ increased from about $100 \mathrm{~kg} / \mathrm{ha}$ at $\mathrm{pH} 3.9$ to over $900 \mathrm{~kg} / \mathrm{ha}$ at $\mathrm{pH} 5.6$ (fig. 18). Soybean yields decreased as percent $\mathrm{Al}$ saturation of the soil increased from about $900 \mathrm{~kg} / \mathrm{ha}$ at $10 \%$ 
Al saturation to about $200 \mathrm{~kg} / \mathrm{ha}$ at about $70 \%$ (fig. 19). The exchangeable Al/base was significantly correlated with soybean yields, with lowest yields obtained at a ratio of 2.5 (fig. 20).

\section{COTO SANDY CLAY (TROPEPTIC HAPLORTHOX)}

This Oxisol is fairly low in $\mathrm{Al}$ as compared with the Ultisols at corresponding $\mathrm{pH}$ values. For example, at a $\mathrm{pH}$ of 4.5 , the $\mathrm{Al}$ concentration of the Coto soil was less than $30 \%$, while in the Humatas and Corozal soils it was about $50 \%$ (table 4).

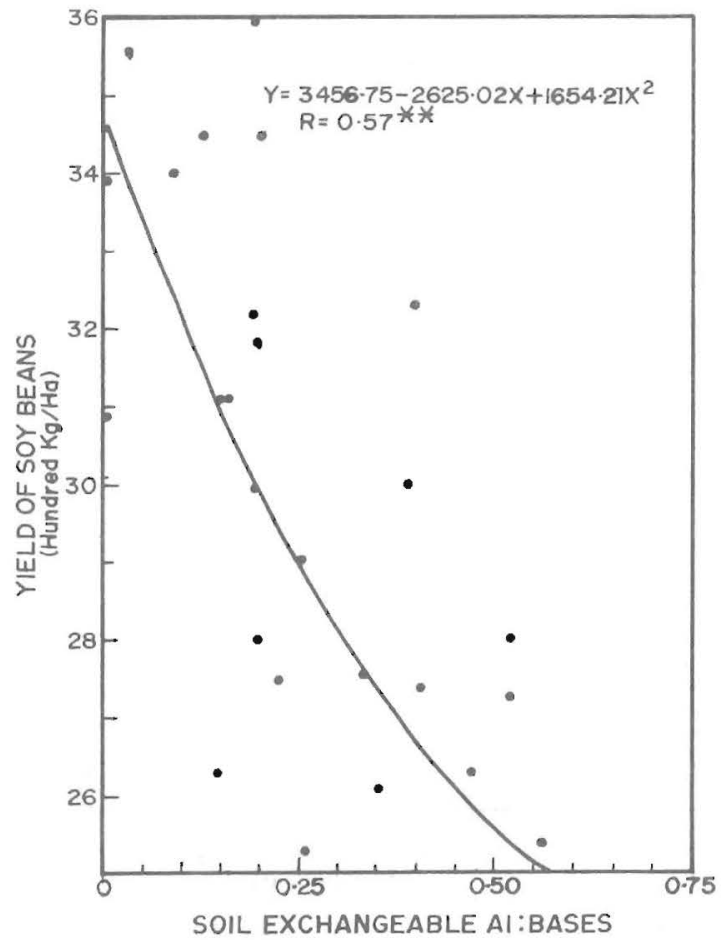

FIG. 23. - Influence of the Al/base ratio of Coto sandy clay on soybean yields.

On the Coto soil there was no significant effect of soil acidity on the $\mathrm{N}$ or Ca contents of the leaves as on the Ultisols. The Mn contents of the soybean leaves, however, were higher in this soil at a given $\mathrm{pH}$ or Al saturation percentage than on the Ultisols. The $\mathrm{Ca} / \mathrm{Mn}$ ratio was significantly affected by soil acidity, the difference being attributable to variable $\mathrm{Mn}$ contents in the presence of a fairly constant Ca content.

This soil produced the highest yields of all at comparable $\mathrm{pH}$ values percent $\mathrm{Al}$ saturations or Al/base ratios. Maximum yields of $3,555 \mathrm{~kg} /$ ha were obtained at 0 to $9 \% \mathrm{Al}$ saturation ( $\mathrm{pH}$ 5.30) and lowest yields of $2,540 \mathrm{~kg} / \mathrm{ha}$ at $\mathrm{pH} 4.3$ over $30 \% \mathrm{Al}$ saturation). 
The three main acidity components $\mathrm{pH}$, percent $\mathrm{Al}$ saturation, and Al/base ratios, were correlated with yields (figs. 21, 22, and 23). The yield response, however, was moderate.

Soybeans responded less to lime on the Oxisol than on the Ultisols, probably because the former is lower in exchangeable Al than the latter at a given level of acidity. However, this Oxisol is higher in exchangeable and easily reducible Mn than the Ultisols, suggesting that Mn toxicity probably was a contributing factor to the soybean response to liming on this soil.

\section{RESUMEN}

Se estudió el efecto de los factores de acidez del suelo en los rendimientos y composición foliar de la soja en tres Ultisoles y un Oxisol de Puerto Rico.

Las variaciones en $\mathrm{pH}$, contenido en bases y aluminio, resultantes del encalado tuvieron un efecto significativo tanto en la producción de semillas como en la composición química del follaje. Como los principales factores que determinan el grado de acidez del suelo están íntimamente relacionados, la respuesta a uno de ellos necesariamente implica la respuesta a los demás, Sin embargo, la intensidad de la respuesta varió entre estos factores, así como entre los suelos. Las mejores correlaciones entre la producción de semillas y los factores de acidez se lograron en los suelos Corozal (Ultisol).

En el suelo Humatas, que es un Ultisol más meteorizado que el Corozal, también se lograron correlaciones significativas entre la producción y los factores de acidez del suelo, aunque no tan pronunciadas como en el suelo y subsuelo Corozal.

En el suelo Coto, único Oxisol del grupo, la soja respondió poco a los factores de acidez, aparentemente porque este suelo contiene menos aluminio que los Ultisoles a valores $\mathrm{pH}$ comparables. La respuesta, aunque leve, puede deberse al elevado contenido en manganeso, fácilmente reducible y/o intercambiable del suelo Coto.

Los contenidos en calcio y nitrógeno en las hojas de la soja sembrada en los Ultisoles varió con los factores de acidez. El contenido en los demás elementos no se alteró. En el Oxisol, sólo el contenido en manganeso en las hojas varió con la acidez del suelo. En términos generales, los rendimientos de soja variaron más con los factores de acidez en los Ultisoles que en los Oxisoles.

Los factores de acideź, pH, saturación de aluminio y razón de aluminio a bases, pueden usarse como índices para determinar la necesidad de encalar.

\section{LITERATURE CITED}

1. Abruña-Rodríguez, F., Pearson, R. W., and Elkins, C., 1958. Quantitative evaluation of soil reaction and base status changes resulting from field applications of residually acid nitrogen fertilizer, Soil Sci. Soc. Am. Proc. 22: 539-42.

2. - , and Vicente-Chandler, J., 1967. Sugarcane yields as related to acidity of a humid tropic Ultisol, Agric. J., 59: 330-1.

3. - - Pearson, R. W., and Silva, S., 1974. Crop response to soil acidity factors in Ultisols and Oxisols, I. Tobacco, Soil Sci. Soc. Am. Proc. 34: 629-35.

4. - - Pérez-Escolar, R., Vicente-Chandler, J., Figarella, J., and Silva, S., 1974. Response of green beans to acidity factors in six tropical soils, J. Agric. Univ. P.R. 58(1): 44-58.

5. — - - - — Pearson, R. W., and Silva, S., 1974. Response of corn to acidity factors in eight tropical soils, J. Agric. Univ. P. R., 58(1): 59-77.

6. Aimiger, W. H., Foy, C. D., Fleming, A. L., and Caldwell, B. E., 1968. Differential tolerance of soybean varieties to an acid soil high in exchangeable aluminum, Agric. J., 60: 67-70.

7. Cheng, K. L., and Bray, R. H., 1951. Determination of calcium and magnesium in soil and plant material, Soil Sc. 72: 449-58.

8. Foster, H. L., 1970. Liming continuously cultivated soils in Uganda, East Afr. Agric. For. J. 36: 58-69. 
9. Mascarenhas, H. A. A., Miyasaka, S., Toshio, I., Freire, E. S., and di Sordi, G., 1969. Respostas da soja à calagem e a adubaçōes minerais con fósforo e potássio em solo Latossolo Roxo, Bragantia 28: XVII-XXI.

10. Mikkelsen, D. S., Freitas, L. M., and McClung, A. C., 1963. Effects of liming and fertilizing cotton, corn and soybeans on Campo Cerrado soils, State of Sāo Paulo, Brazil, IRI Res. Inst. Bull. 29.

11. McLean, E. O., 1965. Aluminum methods of soil analysis, Am. Soc. Agron., Agron. Series No. 9, 994-6.

12. Silva, S., Vicente-Chandler, J., Abruña, F., and Rodríguez, J., 1972. Effect of season and plant spacing on yields of intensively managed soybeans under tropical conditions, J. Agric. Univ. P. R., 56(4): 365-9.

13. Soares, W., Lobato, E., González, E. E., and Naderman, G. C., 1974. Encalado de los suelos del Cerrado Brasileño. Manejo de suelos en la América Tropical, published by Univ. Consortium on Soils of the Tropics, N.C. State Univ. 